\title{
Soil organic carbon storage changes in coastal wetlands of the modern Yellow River Delta from 2000 to 2009
}

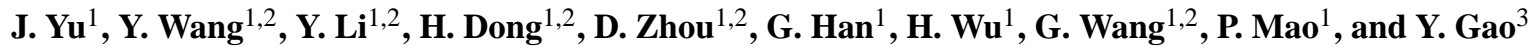 \\ ${ }^{1}$ Key Laboratory of Coastal Zone Environmental Processes, Yantai Institute of Coastal Zone Research (YIC), Chinese \\ Academy of Sciences (CAS); Shandong Provincial Key Laboratory of Coastal Zone Environmental Processes, YICCAS, \\ Yantai Shandong 264003, China \\ ${ }^{2}$ Graduate University of Chinese Academy of Sciences, Beijing 100049, China \\ ${ }^{3}$ Department of Geosciences, University of Houston, Houston, TX 77204, USA
}

Correspondence to: J. Yu (junbao.yu@gmail.com)

Received: 26 December 2011 - Published in Biogeosciences Discuss.: 10 February 2012

Revised: 11 May 2012 - Accepted: 22 May 2012 - Published: 28 June 2012

\begin{abstract}
Soil carbon sequestration plays an essential role in mitigating atmospheric $\mathrm{CO}_{2}$ increases and the subsequently global greenhouse effect. The storages and dynamics of soil organic carbon (SOC) of 0-30 cm soil depth in different landscape types including beaches, reservoir and pond, reed wetland, forest wetland, bush wetland, farmland, building land, bare land (severe saline land) and salt field in the modern Yellow River Delta (YRD) were studied based on the data of the regional survey and laboratory analysis. The landscape types were classified by the interpretation of remote sensing images of 2000 and 2009, which were calibrated by field survey results. The results revealed an increase of $10.59 \mathrm{~km}^{2}$ in the modem YRD area from 2000 to 2009 . The SOC density varied ranging from $0.73 \mathrm{~kg} \mathrm{~m}^{-2}$ to $4.25 \mathrm{~kg} \mathrm{~m}^{-2}$ at depth of $0-30 \mathrm{~cm}$. There were approx. $3.559 \times 10^{6} \mathrm{t}$ and $3.545 \times 10^{6} \mathrm{t}$ SOC stored in the YRD in 2000 and 2009, respectively. The SOC storages changed greatly in beaches, bush wetland, farm land and salt field which were affected dominantly by anthropogenic activities. The area of the YRD increased greatly within 10 years, however, the small increase of SOC storage in the region was observed due to landscape changes, indicating that the modern YRD was a potential carbon sink and anthropogenic activity was a key factor for SOC change.
\end{abstract}

\section{Introduction}

One of the most dramatic changes in the global system resulting from human activity is the rising greenhouse gases (Ogle et al., 2003; Vitousek et al., 1997). The increase in carboncontaining greenhouse gases is presumed to be the basis of current and future climate change (Hansen et al., 2000; Levitus et al., 2001; Schimel et al., 2000; Su et al., 2006). Soil organic carbon (SOC) stock is the largest pool in the terrestrial ecosystem, with a storage of approx. $1500 \mathrm{Pg}$ in the top $100 \mathrm{~cm}$ depth layer, only a small change in storage has an impact on the level of atmospheric gaseous carbon (Desjardins et al., 2007; Feller and Bernoux, 2008; IPCC, 2001; Janzen, 2004; Xu et al., 2011). The organic carbon pool in soils may exceed the amount of carbon (C) in living vegetation by a factor of 2-3 (Lettens et al., 2005; Schlesinger, 1990). Soil carbon sequestration is believed to be one of the cost-effective ways to mitigate $\mathrm{CO}_{2}$ increase and the global greenhouse effect (Janzen, 2004; Xu et al., 2011).

Functioning as the "biological supermarkets" and "kidneys" of the earth, wetlands provide comprehensive ecoenvironmental and productive services in terms of large food chain, climate control, pollution prevention, biodiversity maintenance, bio-productivity protection, and rich genetic material (Costanza et al., 1997; William and James, 2000; Woodward and Wui, 2001). Recent reports have indicated that wetland ecosystems especially peat bogs have a high carbon storage value (Clark et al., 2007; Mariusz et al., 2008; Mcnamaran et al., 2008). About 20\% 25\% of 
the global soil organic carbon reserve is stored in wetlands, even though wetland area only accounts for $4 \% \sim 6 \%$ the earth land. As a huge natural carbon storehouse, wetland plays an important role in the global carbon cycle (Parish and Looi, 1999). The organic carbon stocks of wetland soil are determined by the climate, hydrology, topography, vegetation, type of wetland soil and land utilization condition (Liu and Ma, 2008; Post et al., 2001; Song et al., 2011). Thus, it is important to establish the relationships between the geographical distribution of soil carbon and climate, vegetation, human development and other factors as a basis for assessing the influence of changes in any of these factors on the wetland carbon cycle (Post et al., 1982).

Land use change has significantly affected the carbon cycles both regionally and globally (Lal, 2002; Song et al., 2007). It is reported that about one fourth of anthropogenic carbon dioxide emissions are due to land use change, especially deforestation (Barnett et al., 2005; Ding et al., 2004; Martin et al., 2010). Long-term experimental studies have confirmed that soil organic carbon is highly sensitive to land use changes from native ecosystems, such as forest or grassland, to agriculture systems, resulting in loss of organic carbon (Jenkinson and Rayner, 1977; Martin et al., 2010; Paul et al., 1997). Approximately, a third of carbon emissions brought by land use change caused the reduction of soil organic matter content (OECD, 1996).

The Yellow River Delta (YRD), which is an area with heavy burden of anthropogenic activities and severe impact of land-ocean interaction among the large river deltas in the world, is the broadest, youngest and most efficiently conserved wetland ecological system in the warm temperate zone of China (Han et al., 2006; Xu et al., 2004). Rapid evolution is the typical characteristic of the YRD, because the sediment load delivered into the sea accounts for $6 \%$ of the global rivers sediment load (Milliman and Syvitski, 1992). For the recent years, most of landscape types in the YRD have been changed for seawater intrusion, climate change and anthropogenic activities. To our knowledge, few studies about SOC in the YRD have been reported so far ( $\mathrm{S}$. Wang et al., 2001). In this study, we present SOC storage related to different landscape changes in wetlands of the modern YRD. Our purposes were (a) to understand the landscape area changes in coastal wetlands of the modern YRD, (b) to illustrate the spatial distribution of SOC density, and (c) to estimate the SOC storage changes related with landscape change in coastal wetlands of the modern YRD from 2000 to 2009 .

\section{Material and methods}

\subsection{Study area}

The Yellow River Delta is located in the southern coast of the Bohai Gulf and the western Laizhou Bay $\left(36^{\circ} 55^{\prime}-38^{\circ} 16^{\prime} \mathrm{N}\right.$, $\left.117^{\circ} 31^{\prime}-119^{\circ} 18^{\prime} \mathrm{E}\right)$ with an area of approximately $5400 \mathrm{~km}^{2}$ (Fig. 1a). Based on record of "Outline History of China Water Resources", the Yellow River has changed its major watercourse (about $600 \mathrm{~km}$ from the river mouth) 26 times in the last 2200 years. In this study, the modern YRD $\left(37^{\circ} 26^{\prime}-\right.$ $38^{\circ} 09^{\prime} \mathrm{N}, 118^{\circ} 33^{\prime}-119^{\circ} 18^{\prime} \mathrm{E}$ ) (Fig. 1b), which was formed since the watercourse of the Yellow River changed in 1855 , was selected to evaluate the SOC storage changes because the burden of anthropogenic activities has gradually elevated since then. The climate of the study region belongs to a warm temperate continental monsoon climate with distinctive seasons and a rainy summer. The annual average temperature is $11.7-12.8^{\circ} \mathrm{C}$ and the frost-free period lasts 206 days. The annual average rainfall is $530-630 \mathrm{~mm}$, of which $70 \%$ is in the summer, evaporation is $1900-2400 \mathrm{~mm}$, and the drought index is up to 3.56 (Cui et al., 2009).

The soil is typical saline alluvial soil (Fluvisols, FAO) developed on loess material of the Quaternary period, which was carried by water from the Loess Plateau. The natural vegetation is salt meadow with more than $85 \%$ species are salt tolerant plants and aquatic plants. The predominant species in the region are Suaeda heteropter Kitag, Phragmites australis, Tamarix chinensis Lour., Aeluropus sinenis and Imperata cylindrica (Linn.) Beauv (He et al., 2007).

\subsection{Data and methods}

Landsat Thematic Mapper (TM) digital images with ground resolution of $30 \mathrm{~m}$ of 2000 and 2009 were used to study the landscape change in the study region. All the images were corrected for removing radiometric and atmospheric effects by subtracting the radiance of a "dark pixel" within each band image (Jensen et al., 1993; Lavery et al., 1993), and were geo-referenced and rectified following the procedure by Serra et al. (2003). With the aid of software of ERDAS 9.2 (Leica, USA), the field investigation calibration, a classification system, was established in this study. The performing classification accuracy was $82.58 \%$ in 2000 and $83.75 \%$ in 2009 and the Kappa statistics were $80.09 \%$ in 2000 and $80.06 \%$ in 2009. With support of the software of ArcGIS 9.3 (ESRI, USA), the indexes of landscape were calculated.

According to grid distribution point method, 252 samples (three replicates) of $0-30 \mathrm{~cm}$ soil depth in 84 soil sites were collected in the modern YRD in 2009 (Fig. 1b). The air dry soil samples were kept in sealed plastic bags at $5{ }^{\circ} \mathrm{C}$ to limit the microorganism activities until sieved through a $2 \mathrm{~mm}$ coarse stainless steel sieve for SOC analysis. Roots and other organic matters were removed before SOC analysis. SOC was determined by Total Organic Carbon Analyzer (TOC- $\mathrm{V}_{\mathrm{CPH}}$, Shimadzu, Japan). A cutting ring was used to measure soil bulk density. The SOC density and SOC storage was calculated as Eqs. (1) and (2), respectively.

$\mathrm{SOCD}=\mathrm{SOC} \times \mathrm{BD} \times H \times 0.01$ 


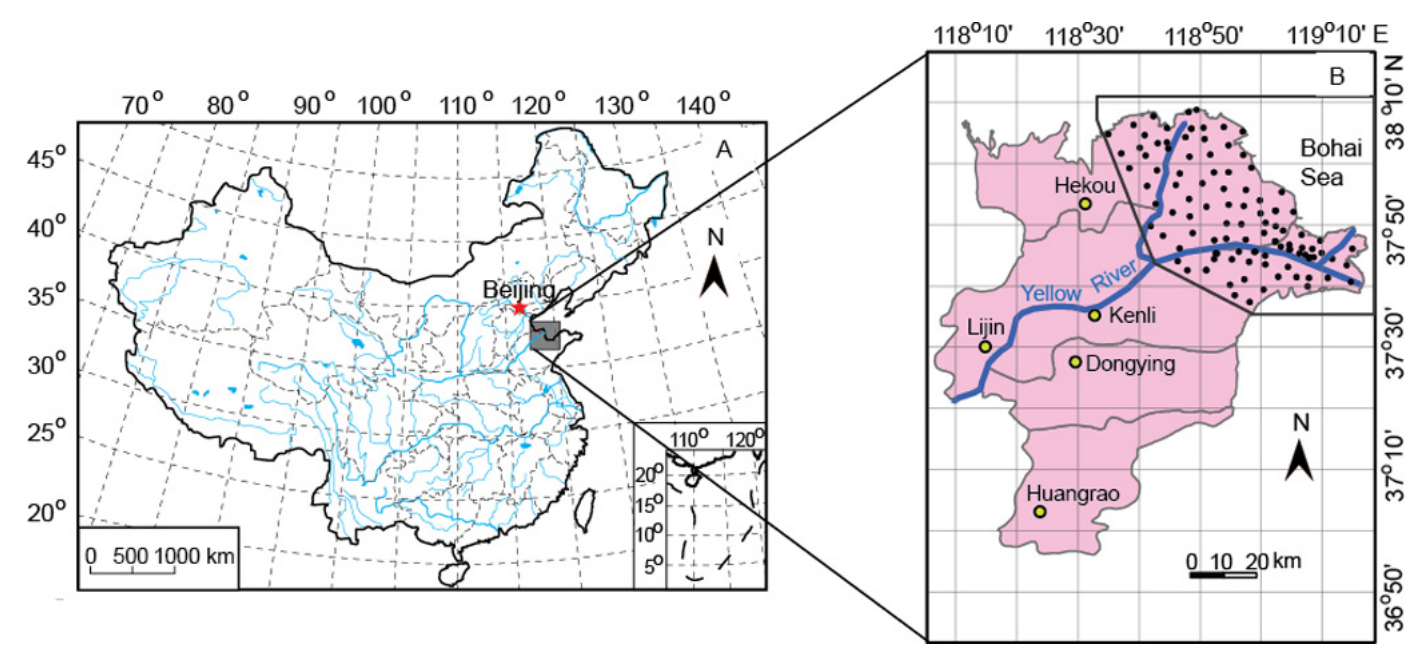

Fig. 1. Location of the modern Yellow River Delta (A), the study region and sample sites (B).
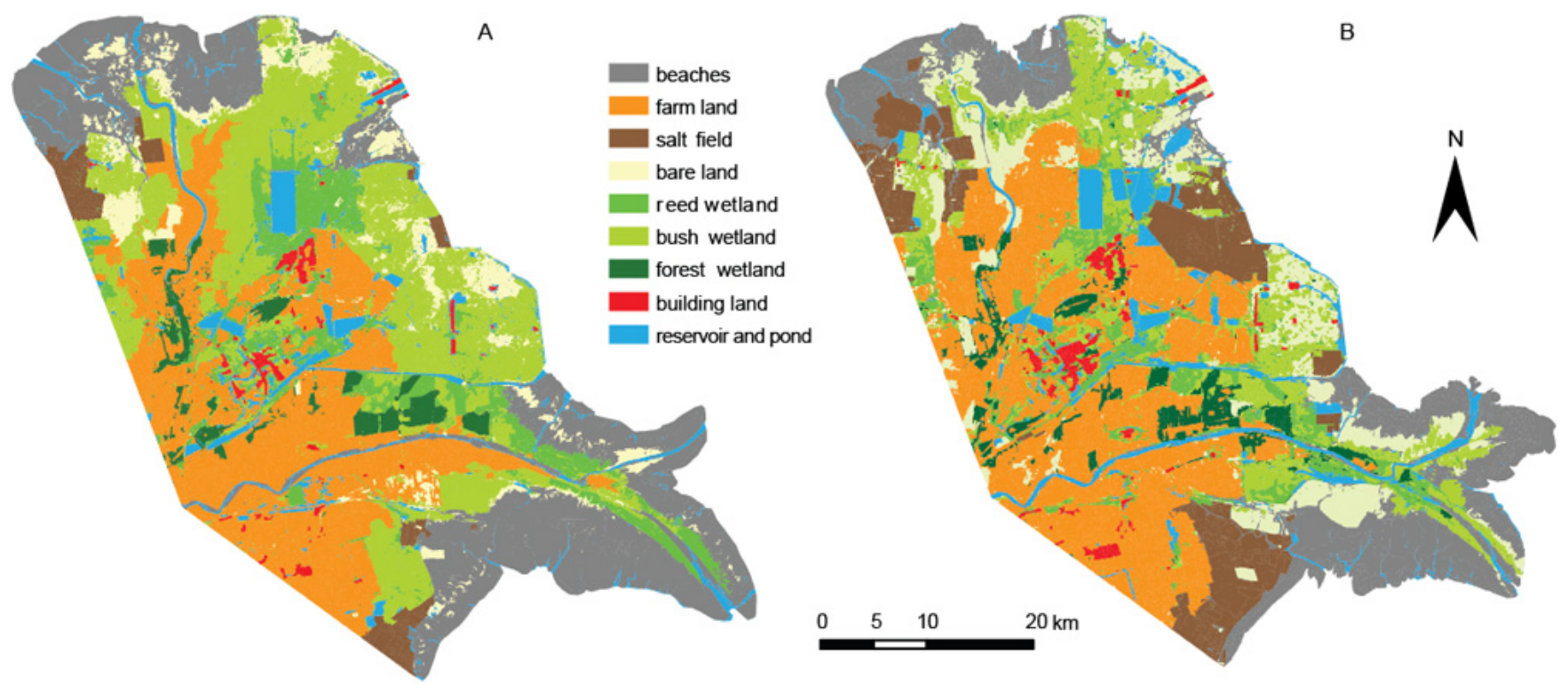

Fig. 2. The landscape types of study area in 2000 (A) and 2009 (B).

SODS $=A \times$ SOCD

Where SOCD is soil organic carbon density $\left(\mathrm{kg} \mathrm{m}^{-2}\right)$, SOC is soil organic carbon content $\left(\mathrm{g} \mathrm{kg}^{-1}\right)$, BD is soil bulk density $\left(\mathrm{g} \mathrm{cm}^{-3}\right), H$ is soil layer height $(\mathrm{cm})$, SODS is soil carbon storage $(\mathrm{kg}), A$ is the area of different landscape types $\left(\mathrm{m}^{2}\right)$. Through RS interpretation, the data of landscape area from TM image were used as well as areas of soil type which were from the second soil census data.

SOC distribution under different landscape was obtained by spatial overlay analysis between field data and RS interpretation images supported by ERDAS 9.2 and ArcGIS 9.3. The field survey of landscapes for the modern YRD was carried out with soil sampled in 2009.

\section{Results}

\subsection{The change of coastal wetland landscapes}

The landscapes in the modern YRD were divided to nine types, i.e. beaches, reservoir and pond, reed wetland, forest wetland, bush wetland, farmland, building land, bare land (severe saline land) and salt field (Fig. 2a, b) based on the interpretation results of remote sensing images by our classification system established. The total area of the wetland is about $2113.20 \mathrm{~km}^{2}$ in 2000 and $2123.79 \mathrm{~km}^{2}$ in 2009 (Table 1). There was an increase of $0.50 \%$ within 10 years, at an average of $1.06 \mathrm{~km}^{2}$ per year. The beaches, reservoir and pond, reed wetland, forest wetland, bush wetland, farm land, building land, bare land, and salt field were about $22.61 \%$, 
Table 1. Comparison of wetland landscapes of 2000 and 2009.

\begin{tabular}{cccccc}
\hline Year & Number of patches & Total area $\left(\mathrm{km}^{2}\right)$ & Mean patches area $\left(\mathrm{km}^{2}\right)$ & Total perimeter $(\mathrm{m})$ & Mean patches perimeter $(\mathrm{m})$ \\
\hline 2000 & 71116 & 2113.20 & 0.029714 & 48030899 & 675.39 \\
2009 & 44333 & 2123.79 & 0.047905 & 37967376 & 856.41 \\
\hline
\end{tabular}

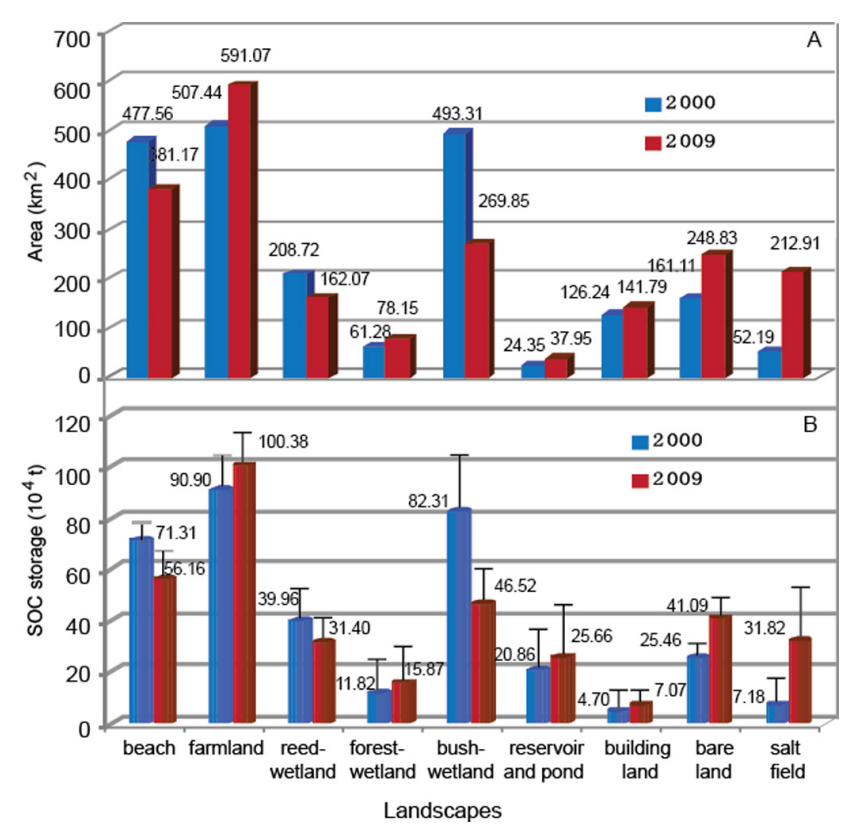

Fig. 3. Comparison of wetland landscape area (A) and SOC storage (B) in the Yellow River Delta from 2000 to 2009. Vertical bars represent standard error.

$5.98 \%, 9.88 \%, 2.90 \%, 23.36 \%, 24.02 \%, 1.15 \%, 7.63 \%$ and $2.47 \%$ of total area in 2000 , respectively, and were about $17.95 \%, 6.68 \%, 7.63 \%, 3.68 \%, 12.71 \%, 27.83 \%$, $1.79 \%, 11.72 \%$, and $10.03 \%$ of total area in 2009 , respectively (Fig. 3a). The number of landscape patch and total patch perimeter was decreased $37.67 \%$ and $20.95 \%$, respectively, while the mean patch area and the mean patch perimeter increased about $0.0182 \mathrm{~km}^{2}$ and $181.02 \mathrm{~m}$ from 2000 to 2009 (Table 1). The patch areas of all landscapes except reed wetland, bush wetland and the beaches tended to increase, especially salt field patch area with about $75.49 \%$ increase (Fig. 2).

\subsection{The distribution of soil organic carbon density}

The soil organic carbon density in $0-30 \mathrm{~cm}$ soil layer was calculated from the SOC and soil bulk density (Eq. 1). The distribution of soil organic carbon density in different landscapes of the modern YRD is shown in Fig. 4, which was generated by the application of the Ordinary Kriging interpolation of the spatial grid method of ArcGIS 9.3 according to the measuring data of organic carbon concentration and

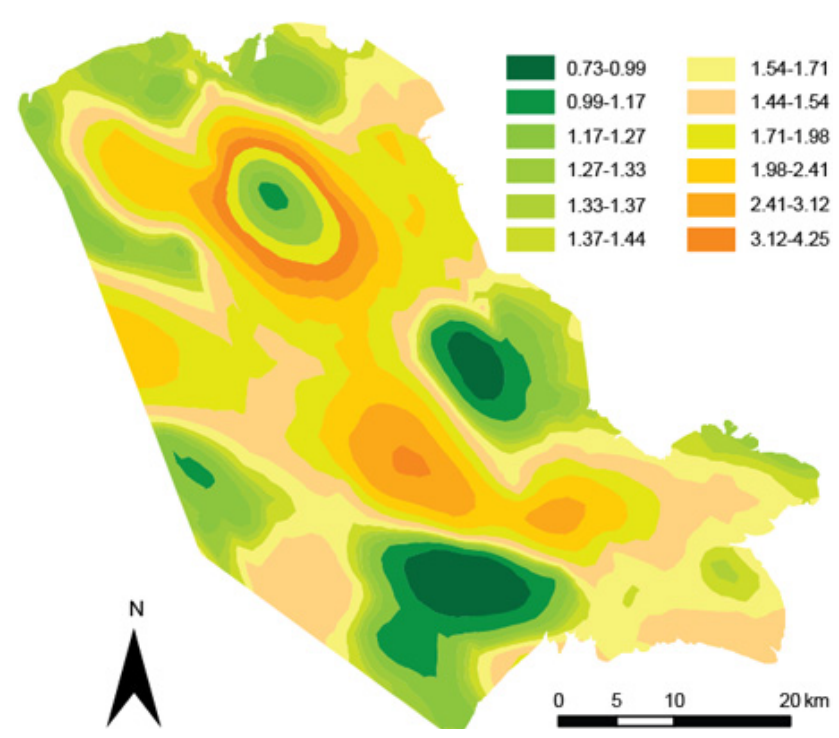

Fig. 4. The distribution of soil organic carbon density in Yellow River Delta.

bulk density in soils sampled in 2009. The results indicated that the SOC densities in $0-30 \mathrm{~cm}$ soil layer in modern YRD ranged from $0.73 \pm 0.95$ to $3.52 \pm 0.68 \mathrm{~kg} \mathrm{~m}^{-2}$. There was more than $57.2 \%$ of total study area with SOC density range of $1.44-2.41 \mathrm{~kg} \mathrm{~m}^{-2}$. Most of them were continuously distributed area of bush wetland, reed wetland, farmland and bare land in the region (Fig. 4). The SOC density ranged from 0.99 to $1.44 \mathrm{~kg} \mathrm{~m}^{-2}$ in separately distributed landscapes of beaches and salt field with an area of $\sim 690.15 \mathrm{~km}^{2}$ accounting for about $32.3 \%$ of total study area. The SOC densities in forest wetland, bush wetland and farmland accounting for $7.4 \%$ of total area of the YRD, which is distributed in the region of the old river channel in north of the YRD, were relatively high $\left(>2.41 \mathrm{~kg} \mathrm{~m}^{-2}\right)$. While the low values $\left(<0.99 \mathrm{~kg} \mathrm{~m}^{-2}\right)$ appeared in bare land and salt field with area of $66.31 \mathrm{~km}^{2}$ (Figs. 2, 4). The highest SOC density $\left(3.52 \mathrm{~kg} \mathrm{~m}^{-2}\right)$ was observed in forest wetland and the lowest value $\left(0.73 \mathrm{~kg} \mathrm{~m}^{-2}\right)$ was found in salt field.

\subsection{The change of carbon storage}

Based on the data of 84 statistical soil profiles, the $0-30 \mathrm{~cm}$ topsoil organic carbon storage of different landscape types in 2000 and 2009 was estimated using Eq. (2) (Fig. 3b). The SOC dynamics during 10 years in YRD were supported by GIS techniques. The results showed that the region's SOC 
Table 2. The transfer matrix of landscape types from 2000 to 2009 in the modern YRD $\left(\mathrm{km}^{2}\right)$ (BW: bush wetland, RP: reservoir and pond, BuL: building land, FW: forest wetland, FL: farm land, Bea: beaches, RW: reed wetland, SF: salt field, BaL: bare land).

\begin{tabular}{crrrrrrrrrr}
\hline 2009 & BW & RP & BuL & FW & FL & Bea & RW & SF & BaL & Total \\
2000 & & & & & & & & & & \\
\hline BW & 131.2 & 20.0 & 3.6 & 7.3 & 129.2 & 9.2 & 55.6 & 70.1 & 67.9 & 494.1 \\
RP & 8.4 & 43.2 & 2.1 & 1.9 & 13.0 & 20.5 & 14.3 & 8.5 & 9.5 & 121.4 \\
BuL & 1.6 & 0.0 & 15.3 & 0.0 & 4.0 & 0.0 & 2.1 & 0.0 & 0.0 & 23.0 \\
FW & 2.5 & 1.1 & 0.0 & 34.2 & 17.2 & 0.0 & 3.9 & 0.0 & 2.2 & 61.1 \\
FL & 24.1 & 13.4 & 11.0 & 23.2 & 367.5 & 1.7 & 27.3 & 2.9 & 35.2 & 506.3 \\
Bea & 17.8 & 25.5 & 0.0 & 1.4 & 3.1 & 258.3 & 4.7 & 47.8 & 69.7 & 428.3 \\
RW & 56.5 & 21.6 & 4.6 & 9.5 & 40.1 & 5.1 & 48.0 & 10.4 & 12.3 & 208.1 \\
SF & 0.0 & 0.0 & 0.0 & 0.0 & 0.8 & 2.0 & 0.0 & 46.5 & 1.3 & 50.6 \\
BaL & 27.0 & 12.4 & 0.8 & 0.4 & 16.3 & 23.3 & 5.7 & 26.3 & 47.5 & 159.7 \\
Total & 269.1 & 137.2 & 37.4 & 77.9 & 591.2 & 320.1 & 161.6 & 212.5 & 245.6 & 2052.6 \\
\hline
\end{tabular}

storages in the $0-30 \mathrm{~cm}$ depth in 2009 and 2000 were about $355.88 \times 10^{4} \mathrm{t}$ and $354.51 \times 10^{4} \mathrm{t}$, respectively, indicating that the change of carbon reserves was small from 2000 to 2009. The biggest organic carbon banks in landscapes of the modern YRD were both farmland with $90.06 \times 10^{4} \mathrm{t}$ in 2000 and $94.85 \times 10^{4} \mathrm{t}$ in 2009 . The carbon storage in paddy field was small both in 2000 and 2009. The decreases of carbon storage mainly occurred in beach, reed wetland and bush wetland, while more increases appeared in farmland, bare land and salt field. From 2000 to 2009, more than $70 \%$ carbon storage was lost in bush wetland and about $9.48 \times 10^{4} \mathrm{t}$ carbon increased in farmland. There were small carbon storage changes in landscapes of forest wetland, reservoir and pond.

\section{Discussions}

The land use changes from anthropogenic activities should be responsible for the wetland landscapes changes in the modern YRD. Landscape changes can be distinguished into conversions from one land-cover type into another one and transformations within a given land-cover type (Yue et al., 2003). Based on the remote sensing data of Landsat TM (2000, 2009), the transfer matrix of landscape types in modern YRD were extracted using ArcGIS software (Table 2). From 2000 to 2009, all wetland landscape areas extended except bush wetland, beaches and reed wetland. The largest increase from 2000 to 2009 was salt field, about $75 \%$ of which was changed from bush wetland, beaches and bare land. While the largest decrease was bush wetland, of which about $45 \%$ was changed to farm land, salt field and bare land. The lost rate of beaches was similar with bush wetland. The area of reservoir and pond was relatively stable with no more than $10 \%$ change. It is well known that the YRD was formed by functions of sea backwater, rich sediment in river and quick deposit at estuary. The Yellow River is regarded as largest contributor of fluvial sediment load to the ocean in the world (Wang and Aubrey, 1987), thus the quick evolution rate of the YRD is unique. A recent study showed that the average area increase rate of the eastern part of the modern YRD had decreased to about $3.94 \mathrm{~km}^{2}$ year ${ }^{-1}$ in 1996-2008, which was only $24.3 \%$ of that in 1986-1995, because of sharp reductions of runoff and sediment load, of which $84 \%-85 \%$ was caused by anthropogenic activities of the construction of reservoirs and dams in the river basin (Yu et al., 2011). We calculated that $\sim 25 \mathrm{~km}^{2}$ was lost by erosion in the northern part of the YRD during the studied period. Even though the total extension rate decreased $\left(\sim 1.06 \mathrm{~km}^{2}\right.$ per year), the area of the YRD still increased gradually. Therefore, it is clear that most of wetland landscape areas extended from 2000 to 2009 (Fig. 3). However, our results showed the area of the typical natural wetlands of bush wetland and reed wetland were reduced greatly (Fig. 3) and most of them were changed to farmland and salt land (Table 2).

Our findings indicated that the change of soil organic carbon reserves in the YRD was mainly caused by anthropogenic activities. The total SOC storage in the modern YRD increased around $1.38 \times 10^{4} \mathrm{t}$ with $10.59 \mathrm{~km}^{2}$ of total area increase during 2000-2009. More than $25 \%$ of total SOC was stored in farmland which increased quickly within the studied period (Fig. 3a, b). The formation history of the modern YRD is no more than 150 years and the east part were formed since 1976. The tillage period of most of farmland, which mainly changed from suitable farming landscapes of bush wetland, reed wetland and forest wetland, is not over 40 years. A previous study found that the potential for different landscape elements to sequester carbon was partly dependent on the changes in SOC stores that occurred since cultivation began (Bedard-Haughn, 2007). We observed that the SOC density farmland with a short-term tillage period was similar with that in reed wetland and bush wetland (Figs. 2 and 4). The conversion of reed wetland and bush wetland to farmland could not change SOC sequestration greatly in a short period. Meanwhile, with the impact of climate change and increasing intensity of human activities, the wetland in 
the study area showed reverse succession. Parts of bush wetland and reed wetland were changed to bare field and salt field besides farmland, and most beaches were changed to bare land. After the degeneration and transformation, the soil water content decreased while soil's air permeability increased. As a result, the function of fixing carbon in soil was weakened (Lili et al., 2009; Liu and Zhang, 2005; Yang et al., 2010). Therefore, it is believed that the declined carbon fixation capacity of coastal wetlands in the modern YRD appear to be soon under such heavy burden of human activities. On the other hand, the SOC content in coastal wetlands of the modern YRD was much lower than that in Plum Island salt marshes, Louisiana coastal wetlands and Quanzhou Bay coastal wetlands in China (Dodla et al., 2008; A. Wang et al., 2007; X. C. Wang et al., 2003), indicating that the coastal wetlands of the YRD also have a huge carbon fixation potential. The present contribution showed that the overall trend of SOC storage from 2000 to 2009 increased. The estimation of SOC reserves of $0-30 \mathrm{~cm}$ topsoil $\left(354.51 \times 10^{4} \mathrm{t}\right)$ is generally consistent with previous results in 0-100 $\mathrm{cm}$ soil in 1992 in the YRD (S. Wang et al., 2001). From the further analysis, we observed that the $0-10 \mathrm{~cm}$ SOC content was much higher than that in other soil layers in coastal wetlands of the YRD, because the root of predominant plant was mainly distributed in $0-10 \mathrm{~cm}$ soil depth and the litter returned to soil surface directly. It suggested that the topsoil protection was the most important to maintain the stability of the soil carbon pool in coastal wetland of the modern YRD.

\section{Conclusion remarks}

The Yellow River Delta is one of three big deltas in China. Under heavy burden of human activities including oil exploration (The Shengli oil field which is the second biggest oil field in China located in the YRD), parts of natural wetlands have changed to farmland, salt field and building land; the natural wetland degradation has been serious and common. Our results showed that only a small increase of SOC storage in coastal wetlands, although the area of the modern YRD extended $10.59 \mathrm{~km}^{2}$ from 2000 to 2009. It demonstrated that anthropogenic activities played a major role in changing landscapes and carbon storage pattern. However, the coastal wetlands of the YRD have a huge potential for carbon fixation. It suggests that the effective measures of returning farmland to wetland and controlling human disturbance should be carried out as early as possible to maintain coastal wetland SOC pool in the modern YRD.

Acknowledgements. We are grateful for support from the Knowledge Innovation Program of the CAS (kzcx2-YW-223), National Natural Science Foundation for Distinguished Young Scholar of Shandong Province (No. JQ201114), Project of National Science \& Technology Pillar Program in "12th Five Year" period (2011BAC02B01) and the CAS/SAFEA international partnership program for creation research team. We thank Yellow River Delta Ecology Research Station of Coastal Wetland, CAS, with the help of field work.

Edited by: X. Wang

\section{References}

Barnett, T. P., Adam, J. C., and Lettenmaier, D. P.: Potential impacts of a warming climate on water availability in snow-dominated regions, Nature, 438, 303-309, 2005.

Bedard-Haughn, A.: The effects of erosional and management history on soil organic carbon stores in ephemeral wetlands of hummocky agricultural landscapes (vol. 135, p. 296, 2006), Geoderma, 138, 272-272, 2007.

Clark, J. M., Lane, S. N., Chapman, P. J., and Adamson, J. K.: Export of dissolved organic carbon from an upland peatland during storm events: Implications for flux estimates, J. Hydrol., 347, 438-447, 2007.

Costanza, R., dArge, R., deGroot, R., Farber, S., Grasso, M., Hannon, B., Limburg, K., Naeem, S., ONeill, R. V., Paruelo, J., Raskin, R. G., Sutton, P., and vandenBelt, M.: The value of the world's ecosystem services and natural capital, Nature, 387, 253260, 1997.

Cui, B. S., Yang, Q. C., Yang, Z. F., and Zhang, K. J.: Evaluating the ecological performance of wetland restoration in the Yellow River Delta, China, Ecol. Eng., 35, 1090-1103, 2009.

Desjardins, R. L., Hutchinson, J. J., and Campbell, C. A.: Some perspectives on carbon sequestration in agriculture, Agr. Forest Meteorol., 142, 288-302, 2007.

Ding, W. X., Cai, Z. C., and Wang, D. X.: Preliminary budget of methane emissions from natural wetlands in China, Atmos. Environ., 38, 751-759, 2004.

Dodla, S. K., Wang, J. J., DeLaune, D. R., and Cook, R.: Denitrification potential and its relation to organic carbon quality in three coastal wetland soils, Sci. Total Environ., 407, 471-480, 2008.

Feller, C. and Bernoux, M.: Historical advances in the study of global terrestrial soil organic carbon sequestration, Waste Manage., 28, 734-740, 2008.

Han, M., Zhang, X., and Liu, L.: Research progress on wetland of the Yellow River Delta, Ecol. Environ., 15, 872-875, 2006.

Hansen, J., Sato, M., Ruedy, R., Lacis, A., and Oinas, V.: Global warming in the twenty-first century:an alternative scenario, Proc. Natl. Acad. Sci. USA, 97, 9875-9880, 2000.

He, Q., Cui, B., Zhao, X., Fu, H., Xiong, X., and Feng, G.: Vegetation distribution patterns to the gradients of water depth and soil salinity in wetlands of Yellow River delta, china, Wetland Sci., 5, 208-214, 2007.

IPCC: Climate change: the scientific basisi, Cambridge University Press, Cambridge, 2001.

Janzen, H. H.: Carbon cycling in earth systems - a soil science perspective, Agr. Ecosyst. Environ., 104, 399-417, 2004.

Jenkinson, D. S. and Rayner, J. H.: Turnover of Soil Organic-Matter in Some of Rothamsted Classical Experiments, Soil Sci., 123, 298-305, 1977.

Jensen, J. R., Narumalani, S., Weatherbee, O., and Mackey, H. E.: Measurement of Seasonal and Yearly Cattail and Waterlily Changes Using Multidate Spot Panchromatic Data, Photogramm. Eng. Rem. S., 59, 519-525, 1993. 
Lal, R.: Soil carbon dynamics in cropland and rangeland, Environ. Pollut., 116, 353-362, 2002.

Lavery, P., Pattiaratchi, C., Wyllie, A., and Hick, P.: Water-Quality Monitoring in Estuarine Waters Using the Landsat Thematic Mapper, Remote Sens. Environ., 46, 268-280, 1993.

Lettens, S., van Orshoven, J., van Wesemael, B., Muys, B., and Perrin, D.: Soil organic carbon changes in landscape units of Belgium between 1960 and 2000 with reference to 1990, Glob. Change Biol., 11, 2128-2140, 2005.

Levitus, S. J., Antonov, I., Wang, J., Delworth, T. L., Dixon, K. W., and Baldocchi, A. J.: Anthropogenic warming of the earth's climate system, Science, 292, 267-270, 2001.

Lili, W., Changchun, S., Ruijuan, G., YanYu, S., and DeYan, L.: Soil organic carbon storage under different land-use types in Sanjiang Plain, China Environ. Sci., 29, 656-660, 2009 (in Chinese).

Liu, Z. G. and Ma, X. H.: Overview of Wetlands in China, China forestry publishing house, Beijing, 2008 (in Chinese).

Liu, Z. and Zhang, K.: Wetland soils carbon stock in the Sanjiang Plain, Journal-Tsinghua University, 45, 788-791, 2005 (in Chinese).

Mariusz, L., Milena, O., and Edward, A. D.: Autogenic succession,landuse change, and climatic influences on the Holocene development of a kettle-hole mire in Northern Polan, Rev. Palaeobot. Palyno., 151, 21-40, 2008.

Martin, D., Lal, T., Sachdev, C. B., and Sharma, J. P.: Soil organic carbon storage changes with climate change, landform and land use conditions in Garhwal hills of the Indian Himalayan mountains, Agr. Ecosyst. Environ., 138, 64-73, 2010.

Mcnamaran, P., Plant, T., and Oakley, S.: Gully hotspot contribution to landscape methane $\left(\mathrm{CH}_{4}\right)$ and carbon dioxide $\left(\mathrm{CO}_{2}\right)$ fluxes in a northern peatland, Sci. Total Environ., 404, 354-360, 2008.

Milliman, J. D. and Syvitski, J. P. M.: Geomorphic Tectonic Control of Sediment Discharge to the Ocean - the Importance of Small Mountainous Rivers, J. Geol., 100, 525-544, 1992.

OECD: Guidelines for aid agencies for improved conservation and sustainable use of tropical and subtropical wetlands. Organization for Economic Co-operation and Development, Paris, France, 1996.

Ogle, S. M., Breidt, F. J., Eve, M. D., and Paustian, K.: Uncertainty in estimating land use and management impacts on soil organic carbon storage for US agricultural lands between 1982 and 1997 , Glob. Change Biol., 9, 1521-1542, 2003.

Parish, F. and Looi, C. C.: Wetlands, biobiversity and clumate change opnions and needs fro enhanced linkage between the Ramsar conventions on wetland, Tokio, 1999.

Paul, E. A., Follett, R. F., Leavitt, S. W., Halvorson, A., Peterson, G. A., and Lyon, D. J.: Radiocarbon dating for determination of soil organic matter pool sizes and dynamics, Soil Sci. Soc. Am. J., 61, 1058-1067, 1997.

Post, W. M., Emanuel, W. R., Zinke, P. J., and Stangenberger, A. G.: Soil Carbon Pools and World Life Zones, Nature, 298, 156-159, 1982.

Post, W. M., Izaurralde, R. C., Mann, L. K., and Bliss, N.: Monitoring and verifying changes of organic carbon in soil, Climatic Change, 51, 73-99, 2001.

Schimel, D., Melillo, J., Tian, H. Q., McGuire, A. D., Kicklighter, D., Kittel, T., Rosenbloom, N., Running, S., Thornton, P., Ojima, D., Parton, W., Kelly, R., Sykes, M., Neilson, R., and Rizzo, B.: Contribution of increasing $\mathrm{CO}_{2}$ and climate to carbon storage by ecosystems in the United States, Science, 287, 2004-2006, 2000.

Schlesinger, W. H.: Evidence from Chronosequence Studies for a Low Carbon-Storage Potential of Soils, Nature, 348, 232-234, 1990.

Serra, P., Pons, X., and Sauri, D.: Post-classification change detection with data from different sensors: some accuracy considerations, Int. J. Remote Sens., 24, 3311-3340, 2003.

Song, C. C., Zhang, J. B., and Wang, S. M.: Dynamics of soil organic carbon and its fractions after abandonment of cultivated wetlands in northeast China, Soil Till. Res., 96, 350-360, 2007.

Song, C. C., Wang, L. L., Guo, Y. D., Song, Y. Y., Yang, G. S., and Li, Y. C.: Impacts of natural wetland degradation on dissolved carbon dynamics in the Sanjiang Plain, Northeastern China, J. Hydrol., 398, 26-32, 2011.

Su, Z. Y., Xiong, Y. M., and Zhu, J. Y.: Soil Organic Carbon Content and Distribution in a Small Landscape of Dongguan, South China, Pedosphere, 16, 10-17, 2006.

Vitousek, P. M., Mooney, H. A., Lubchenco, J., and Melillo, J. M.: Human domination of Earth's ecosystems, Science, 277, 494499, 1997.

Wang, Y. and Aubrey, D. G.: The Characteristics of the China Coastline, Cont. Shelf Res., 7, 329-349, 1987 (in Chinese).

Wang, A., Chen, J., Li, D., and Zhou, Z.: Spatial Variations of Carbon and Nitrogen in Coastal Wetland Sediments of Quanzhou Bay in China, Environ. Sci., 28, 2361-2368, 2007 (in Chinese).

Wang, S., Xu, J., and Zhou, C.: The Effect of Land Cover Change on Carbon Cycle: A case study in the Estuary of Yellow River Delta, J. Remote Sens., 5, 142-146, 2001.

Wang, X. C., Chen, R., and Berry, A.: Sources and preservation of organic matter in Plum Island salt marsh sediments (MA, USA): long-chain n-alkanes and stable carbon isotope compositions, Estuar. Coast. Shelf S., 58, 917-928, 2003.

William, J. and James, G. G.: Wetlands, John Wiley, New York, 2000.

Woodward, R. T. and Wui, Y. S.: The economic value of wetland services: a meta-analysis, Ecol. Econ., 37, 257-270, 2001.

Xu, N. Z., Zhang, T. L., Wang, X. X., and Liu, H. Y.: Soil organic carbon storage changes in Yangtze Delta region, China, Environ. Earth Sci., 63, 1021-1028, 2011 (in Chinese).

$\mathrm{Xu}, \mathrm{X}$. G., Lin, H. P., and Fu, Z. Y.: Probe into the method of regional ecological risk assessment - a case study of wetland in the Yellow River Delta in China, J. Environ. Manage., 70, 253-262, 2004 (in Chinese).

Yang, Y. H., Chen, Y. N., Li, W. H., and Chen, Y. P.: Distribution of soil organic carbon under different vegetation zones in the Ili River Valley, Xinjiang, J. Geogr. Sci., 20, 729-740, 2010 (in Chinese).

Yu, J., Fu, Y., Li, Y., Han, G., Wang, Y., Zhou, D., Sun, W., Gao, Y., and Meixner, F. X.: Effects of water discharge and sediment load on evolution of modern Yellow River Delta, China, over the period from 1976 to 2009, Biogeosciences, 8, 2427-2435, doi:10.5194/bg-8-2427-2011, 2011.

Yue, T. X., Liu, J. Y., Jorgensen, S. E., and Ye, Q. H.: Landscape change detection of the newly created wetland in Yellow River Delta, Ecol. Model., 164, 21-31, 2003. 